\title{
Climate change and the world's river basins: anticipating management options
}

\author{
Margaret A Palmer ${ }^{1,2 *}$, Catherine A Reidy Liermann ${ }^{3}$, Christer Nilsson ${ }^{3}$, Martina Flörke ${ }^{4}$, Joseph Alcamo ${ }^{4}$, \\ P Sam Lake ${ }^{5}$, and Nick Bond ${ }^{5}$
}

\begin{abstract}
Major rivers worldwide have experienced dramatic changes in flow, reducing their natural ability to adjust to and absorb disturbances. Given expected changes in global climate and water needs, this may create serious problems, including loss of native biodiversity and risks to ecosystems and humans from increased flooding or water shortages. Here, we project river discharge under different climate and water withdrawal scenarios and combine this with data on the impact of dams on large river basins to create global maps illustrating potential changes in discharge and water stress for dam-impacted and free-flowing basins. The projections indicate that every populated basin in the world will experience changes in river discharge and many will experience water stress. The magnitude of these impacts is used to identify basins likely and almost certain to require proactive or reactive management intervention. Our analysis indicates that the area in need of management action to mitigate the impacts of climate change is much greater for basins impacted by dams than for basins with free-flowing rivers. Nearly one billion people live in areas likely to require action and approximately 365 million people live in basins almost certain to require action. Proactive management efforts will minimize risks to ecosystems and people and may be less costly than reactive efforts taken only once problems have arisen.
\end{abstract}

Front Ecol Environ 2008; 6(2): 81-89, doi:10.1890/060148

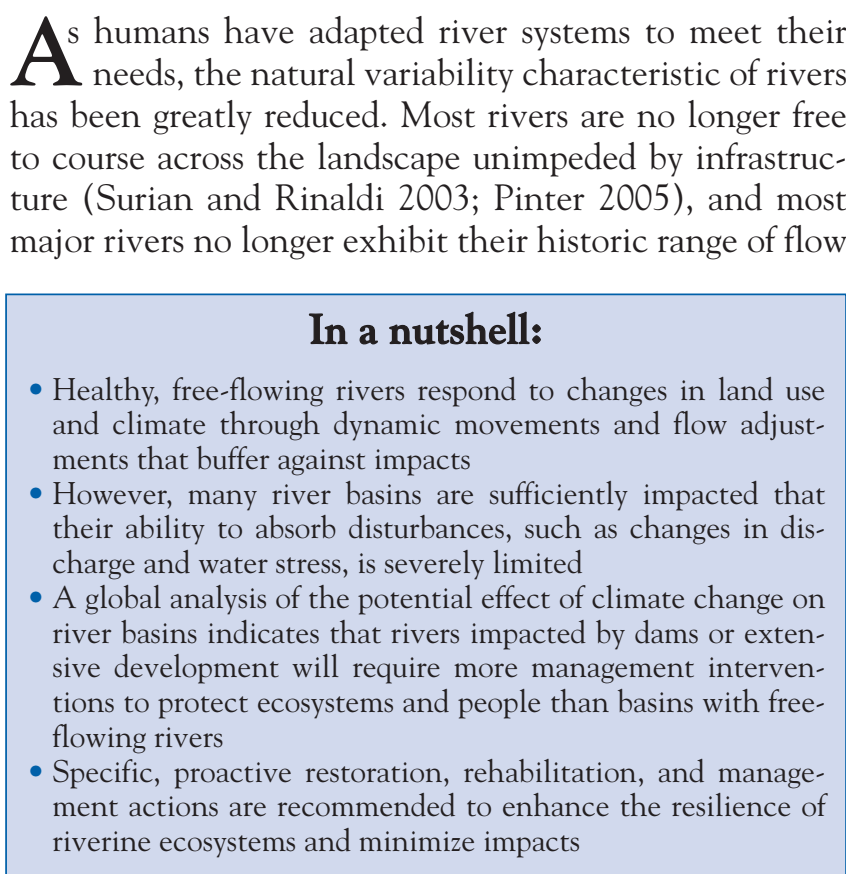

${ }^{1}$ Chesapeake Biological Laboratory, University of Maryland Center for Environmental Science, Solomons, MD 20688; ${ }^{2}$ Department of Entomology, University of Maryland, College Park, MD 20742 *(palmer@cbl.umces.edu); ${ }^{3}$ Landscape Ecology Group, Department of Ecology and Environmental Science, Umeå University, SE-901 87 Umeå, Sweden; ${ }^{4}$ Center for Environmental Systems Research, University of Kassel, Kurt-Wolters-Straße 3, 34109 Kassel, Germany; 5 School of Biological Sciences, Monash University, Clayton, Victoria, Australia variability (Postel and Richter 2003; Poff et al. 2007). Yet, flow variability over time and space is a fundamental characteristic of natural rivers and a river's "flow regime", in concert with sediment inputs, determines not only geomorphic adjustments, but biotic composition and rates of key ecosystem processes, such as primary production (Poff et al. 1997). These adjustments, which include the lateral migration of channels and dynamic interactions between the streambed, floodplain, and riparian zone, are part of a healthy river's response to changes in the surrounding landscape and changes in discharge. In fact, these adjustments allow rivers to absorb disturbances and buffer the ecosystem and surrounding land from the impacts of floods and anthropogenic effects.

The ability of rivers and their biota to respond to altered flow regimes is not, however, unbounded. Changes brought on by urbanization, excessive water withdrawals, or climate shifts that occur rapidly and lead to flows outside the natural range of variability will have important consequences for river ecosystems and the people who depend on them (Lettenmaier et al. 1999; Poff et al. 2002; Palmer et al. 2007). Native riverine biodiversity and productivity may decline, water quality for human consumption may be compromised, and in some regions, the risk of flooding, with concomitant damage to property and people, may increase (Bunn and Arthington 2002; Allan et al. 2005; Naiman et al. 2005).

While the effects of global change on water availability and sustainability of river ecosystem services have received attention (Vörösmarty et al. 2000; Alcamo et al. 2003a; Milly et al. 2005; Schröter et al. 2005), the overlapping impacts of climate change and the impacts caused 


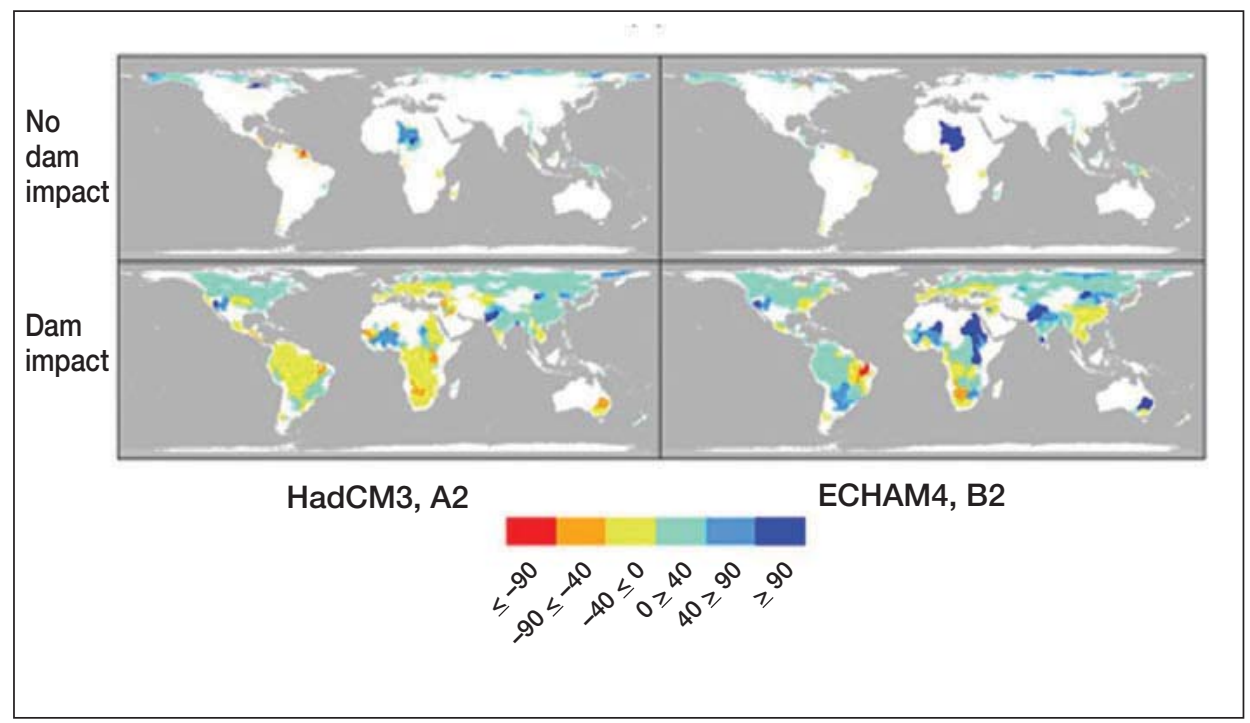

Figure 1. Computed relative change (\%) in river discharge for free-flowing and dam-impacted large river systems from present to 2050s. The climate model output and IPCC scenario combinations presented (HadCM3, A2 and ECHAM4, B2) represent the widest range of results found among all combinations examined. $+\%$ change (blue) $=$ increased discharge; -\% change $(r e d)=$ decreased discharge .

by dams and other human infrastructure have not been explored at global scales. Since many rivers are already under a great deal of stress due to excessive water withdrawal or land development, and this stress may be exacerbated by changes in climate, anticipating and planning adaptive strategies (Hulme 2005) may be critical. The identification and prioritization of actions that can be taken now to enhance the resilience of riverine ecosystems in the face of disturbance may minimize impacts, such as biodiversity loss or severe flooding. Even if no actions are taken at this time, identifying coping options should help prepare societies for dealing with climateinduced problems as they arise.

We used a global water-resources model (Alcamo et al. 2003a), a database on impounded rivers (Nilsson et al. 2005), and a management action and river restoration/rehabilitation classification scheme (modified after Bernhardt et al. [2005]) to explore the future of dammed and free-flowing rivers (as of today), given expected changes in climate and human population. We identified the major river basins likely to experience the greatest changes and the types of actions that may mitigate these impacts, distinguishing between proactive and reactive responses. The former includes actions that, if implemented, will improve the capacity of river systems to absorb disturbances while minimizing threats to the environment and human populations. The latter involves responding to problems as they are generated by repairing damage or by mitigating ongoing impacts. While detailed forecasts of the impacts of climate change on specific river basins are important (Payne et al. 2004), our goal here is to focus on the broad categories of problems that the world's river basins are likely to experience and to provide examples of actions that may mitigate these problems.
Identifying river basins of concern

Our analysis was global in scope, focusing on the scale of major river basins. Data on the impact of dams on large river basins (Nilsson et al. 2005) and on projected river discharge (combined surface runoff and groundwater recharge) under different climate and water withdrawal scenarios for the 2050s were synthesized to create global maps describing potential changes in river discharge and expected water stress for both dam-impacted and unimpacted basins (Figures 1 and 2). We then used 12 of the 13 strategies of river management presented in Bernhardt et al. (2005) to identify actions that may mitigate the potential impacts of future water use and climate change. For river basins without dams, we added a layer of resolution by distinguishing between basins with little development and those with high levels of development (large proportions of impervious coverage; Global Land Cover 2000 Database 2003).

We used the WaterGAP model (Alcamo et al. 2003a; Döll et al. 2003) to estimate changes in river discharge (combined surface runoff and groundwater recharge) and water stress for the 2050s. WaterGAP is an integrated water-resources model, which computes both water use and availability (river discharge and groundwater recharge) on a $0.5^{\circ} \times 0.5^{\circ}$ global grid. The Global Water Use Model consists of sub-models for computing water withdrawals and water consumption in the domestic, manufacturing, electricity, irrigation, and livestock sectors. Water withdrawals are an estimate of the total volume of water abstracted for each sector and water consumption refers to the fraction of water withdrawals that is lost to evapotranspiration or consumed by industrial products or humans. Most of the water withdrawn is returned to the environment for further use, but its quality is often degraded. The global hydrology model estimates river discharge by simulating the characteristic macro-scale behavior of the terrestrial water cycle. Discharge is computed on a global geographic grid $\left(0.5^{\circ} \times 0.5^{\circ}\right)$, based on daily water balances of soil and the vegetation canopy. These water balance computations are driven by precipitation, temperature, and other climate data. A water balance is also performed for open waters, and river flow is directed through a global flow routing scheme. Discharge calculations have been calibrated to annual runoff data from a network of stations covering approximately $50 \%$ of the earth's terrestrial sur- 
face outside of the ice cap. Most stations were calibrated with continuous time series data from several decades. In a standard global run, the discharges in approximately 11050 river basins are estimated.

Here, we analyze the implications of the A2 and B2 scenarios of the Intergovernmental Panel on Climate Change (IPCC 2000) for water use and river discharge. Some of the uncertainty of future climate is addressed by using scenarios from both the HadCM3 and ECHAM4 climate models. The A2 and B2 scenarios make contrasting assumptions about population, economic growth, and technology, which results in differences between scenarios with respect to projected regional water withdrawals in 2050 (Alcamo et al. 2007). Likewise, these contrasting socioeconomic assumptions lead to different emissions pathways up to 2050 and therefore to different levels of regional climate change. While there is ample evidence that water use efficiency is improving in many parts of the world, in most developing countries, the growing demand for water due to increasing wealth and population is likely to overwhelm this trend toward efficiency over the next few decades (Alcamo et al. 2005, 2007).

Interpreting the model results requires consideration of uncertainties, including the input assumptions of the analysis (ie uncertain trends in water withdrawals and climate, which determine future river discharge and stress). We therefore analyzed and report results from two contrasting cases for 2050, based on two distinct sets of socioeconomic driving forces and climate projections (see Alcamo et al. 2007). Estimates are also uncertain because of the uncertainty of the underlying model (WaterGAP). Based on the "goodness" of the model calibration (see WebFigure 1), the uncertainty of estimated river discharge is "medium" in approximately $43 \%$ of the world's large river basins, "lower" in 32\%, and "higher" in 25\% (WebFigure 1). Using stochastic simulation, Kaspar (2004) quantified the parameter and input uncertainties of WaterGAP and determined that the latter had a larger impact on estimates of future river discharge than parameter uncertainty. Using qualitative ranking based on goodness-of-fit and other criteria, Alcamo et al. (2003b) estimated the geographic variation of different types of model uncertainty. Collectively, these analyses suggest that we have covered a substantial part of the expected uncertainty by examining two contrasting cases of socioeconomic driving forces and climate projections. Furthermore, while the reliability of the results is lower for some regions, the output is sufficient for the coarsescale analysis required to explore trends at a global scale.
We chose two thresholds for prioritizing management action among river basins, based on changes in discharge and water stress to the 2050s, and using data presented in Figure 1. We specified that basins were "likely to require action" to mitigate impacts when combined thresholds of discharge decreased or increased by more than $40 \%$ but less than 90\%, and when water stress was at least 0.2 but less than 0.4 (using the withdrawals-to-availability-ratio as an indicator of stress). We derived the threshold of $>40 \%$ change in discharge from Tennant's environmental flow methodology, which recommends $60-100 \%$ of mean annual flow as "optimal" for riverine fishes (Tennant 1976). Although this value was derived for fish in cases of flow reduction, it serves as a conservative basin-wide benchmark for examining the effects of both increases and decreases in flow on ecological function in rivers, and is one of the few environmental flow methods that can be applied at global scales which are, by necessity, approximate at best (eg the method only requires estimates of mean annual flow). General methods for estimating environmental water needs at broad scales (ie methods without site-specific data requirements) are difficult to develop and, currently, the Tennant method (or a modified version of it) is the approach most widely used for such applications (Tharme 2003).

For the threshold of water stress $>0.2$, we drew upon many scientific publications and assessments (Vörösmarty et al. 2000; Cosgrove and Rijsberman 2002; Alcamo et al. 
Table 1. Modeled current and future discharge as computed by WaterGAP for mouths of selected large river systems (for full list of results for all basins see WebTable 1); results reflect the HadCM3 climate change model and A2 scenario

\begin{tabular}{|c|c|c|c|c|}
\hline & & $\begin{array}{c}\text { Discharge } \\
1960 \mathrm{~s} \\
\left(\mathrm{~km}^{3} \mathrm{yr}^{-1}\right)^{*}\end{array}$ & $\begin{array}{c}\text { Discharge } \\
2050 \mathrm{~s} \\
\left(\mathrm{~km}^{3} \mathrm{yr}^{-1}\right)\end{array}$ & $\begin{array}{l}\text { Relative } \\
\text { change } \\
(\%)\end{array}$ \\
\hline \multicolumn{5}{|l|}{ Africa } \\
\hline Dam unimpacted & $\begin{array}{l}\text { Kouilou } \\
\text { Cross } \\
\text { Chari }\end{array}$ & $\begin{array}{l}28.4 \\
59.9 \\
29.1\end{array}$ & $\begin{array}{l}20.0 \\
61.8 \\
34.3\end{array}$ & $\begin{array}{r}-29.6 \\
3.1 \\
17.9\end{array}$ \\
\hline Dam impacted & $\begin{array}{l}\text { Senegal } \\
\text { Congo (Zaire) } \\
\text { Volta }\end{array}$ & $\begin{array}{r}5.7 \\
1349.0 \\
32.8\end{array}$ & $\begin{array}{r}2.5 \\
1267.5 \\
48.1\end{array}$ & $\begin{array}{r}-56.0 \\
-6.0 \\
46.7\end{array}$ \\
\hline \multicolumn{5}{|l|}{ Asia } \\
\hline Dam unimpacted & $\begin{array}{l}\text { Cá } \\
\text { Chu Salween (Thanlwin) } \\
\text { Nadym }\end{array}$ & $\begin{array}{l}22.3 \\
98.5 \\
16.0\end{array}$ & $\begin{array}{r}20.8 \\
135.2 \\
26.5\end{array}$ & $\begin{array}{l}-6.7 \\
37.2 \\
65.9\end{array}$ \\
\hline Dam impacted & $\begin{array}{l}\text { Kura } \\
\text { Ganges-Brahmaputra } \\
\text { Indus }\end{array}$ & $\begin{array}{r}22.0 \\
1186.9 \\
121.2\end{array}$ & $\begin{array}{r}13.7 \\
1388.4 \\
174.6\end{array}$ & $\begin{array}{r}-37.8 \\
17.0 \\
44.1\end{array}$ \\
\hline \multicolumn{5}{|l|}{ Australasia } \\
\hline Dam unimpacted & $\begin{array}{l}\text { Merauke } \\
\text { Fly } \\
\text { Sepik }\end{array}$ & $\begin{array}{r}1.5 \\
135.4 \\
100.7\end{array}$ & $\begin{array}{r}0.9 \\
147.5 \\
133.6\end{array}$ & $\begin{array}{r}-40.6 \\
9.0 \\
32.7\end{array}$ \\
\hline Dam impacted & $\begin{array}{l}\text { Murray } \\
\text { Ramu }\end{array}$ & $\begin{array}{l}11.1 \\
32.7\end{array}$ & $\begin{array}{r}9.5 \\
40.1\end{array}$ & $\begin{array}{r}-14.3 \\
22.8\end{array}$ \\
\hline \multicolumn{5}{|l|}{ Europe } \\
\hline Dam unimpacted & $\begin{array}{l}\text { Adour } \\
\text { Pechora } \\
\text { Mezen }\end{array}$ & $\begin{array}{r}6.5 \\
142.0 \\
26.5\end{array}$ & $\begin{array}{r}6.2 \\
174.1 \\
32.8\end{array}$ & $\begin{array}{r}-4.9 \\
22.6 \\
23.8\end{array}$ \\
\hline Dam impacted & $\begin{array}{l}\text { Kuban } \\
\text { Volga } \\
\text { Severn, Dvina }\end{array}$ & $\begin{array}{r}13.0 \\
234.0 \\
101.2\end{array}$ & $\begin{array}{r}9.7 \\
246.3 \\
123.4\end{array}$ & $\begin{array}{r}-25.1 \\
5.2 \\
21.9\end{array}$ \\
\hline \multicolumn{5}{|c|}{ North and Central America } \\
\hline Dam unimpacted & $\begin{array}{l}\text { Patuca } \\
\text { Yukon } \\
\text { Kobuk }\end{array}$ & $\begin{array}{r}12.3 \\
187.2 \\
0.2\end{array}$ & $\begin{array}{r}3.4 \\
246.0 \\
0.8\end{array}$ & $\begin{array}{r}-72.0 \\
31.4 \\
212.2\end{array}$ \\
\hline Dam impacted & $\begin{array}{l}\text { Grande de Matagalpa } \\
\text { Mississippi } \\
\text { Colorado }\end{array}$ & $\begin{array}{r}30.1 \\
530.6 \\
1.3\end{array}$ & $\begin{array}{r}7.7 \\
540.0 \\
2.4\end{array}$ & $\begin{array}{r}-74.3 \\
1.8 \\
81.6\end{array}$ \\
\hline \multicolumn{5}{|l|}{ South America } \\
\hline Dam unimpacted & $\begin{array}{l}\text { Coppename } \\
\text { Essequibo } \\
\text { Santa Cruz }\end{array}$ & $\begin{array}{r}10.7 \\
155.1 \\
0.9\end{array}$ & $\begin{array}{r}0.7 \\
78.8 \\
1.0\end{array}$ & $\begin{array}{r}-93.4 \\
-49.2 \\
17.3\end{array}$ \\
\hline Dam impacted & $\begin{array}{l}\text { Parnaiba } \\
\text { Amazonas-Orinoco } \\
\text { Doce }\end{array}$ & $\begin{array}{r}26.6 \\
6802.4 \\
24.4\end{array}$ & $\begin{array}{r}5.0 \\
5536.5 \\
33.4\end{array}$ & $\begin{array}{r}-81.2 \\
-18.6 \\
37.1\end{array}$ \\
\hline \multicolumn{5}{|c|}{$\begin{array}{l}\text { Notes: River mouths predicted to show the largest reductions and increases, respectively, in relative dis- } \\
\text { charge, plus the rivers with the largest discharge (1960s-1990s), are presented for each category } \\
\text { "WaterGAP discharge values shown here may differ from locally observed mean annual discharge values or } \\
\text { virgin mean annual discharge values published in Nilsson et al. (2005). These differences may reflect actual } \\
\text { shifts in discharge over time, or uncertainty of the model. Regardless, the relative change in discharge for } \\
\text { each large river system provides a useful indication of the direction and magnitude of change in discharge } \\
\text { expected to result from climate and water-use changes between now and 2050s. }\end{array}$} \\
\hline
\end{tabular}

2003a) that use this value as a standard of "medium" water stress. (We note that these thresholds are correlated with each other since the indicator for water stress - the withdrawals-to-availability ratio uses river discharge in its denominator.) To define basins "nearly certain to require action" to mitigate climate change impacts, we chose a threshold of a $>90 \%$ change in discharge (proposed by Tennant as causing extreme threats to fish survival) and a $>0.4$ change in water stress (used by Vörösmarty et al. [2000], Cosgrove and Rijsberman [2002], and Alcamo et al. [2003a] to indicate "severe" water stress). While we recognize the weakness of any single measure to indicate important change across river basins, we believe that a combination of indices adds robustness to assessments. Such assessments, performed at regional or sub-basin scales, might use different thresholds, based on local conditions and concerns in the context of regionspecific population and climate change projections.

\section{Expected changes in discharge and water stress}

Each populated continent will experience both increases and decreases in river discharge (Figure 1; Table 1). Areas of large river basins likely to require some form of management intervention amount to approximately $300000 \mathrm{~km}^{2}$ for basins with no dam impacts and 10 million $\mathrm{km}^{2}$ for dam-impacted basins (representing $<1 \%$ and $13 \%$ of the world's large river basin area, respectively), and come to represent $7 \%$ of the entire world's area when summed. Nearly one billion people currently live in those areas likely to require action (CIESIN and CIAT 2005). Basins of this category not impacted by dams include the developed Catatumbo in Venezuela, and parts of the less developed Salween in south Asia. Dam-impacted basins in which intervention will probably be required include several in western North America (eg Colorado, parts of the Columbia and Sacramento basins), the San Juan in Central America, Sao Francisco and Mearim in South America, several western African basins (Senegal, Volta, Niger), the Tigris-Euphrates of the Middle East, Syr-Darya and Ili in central 

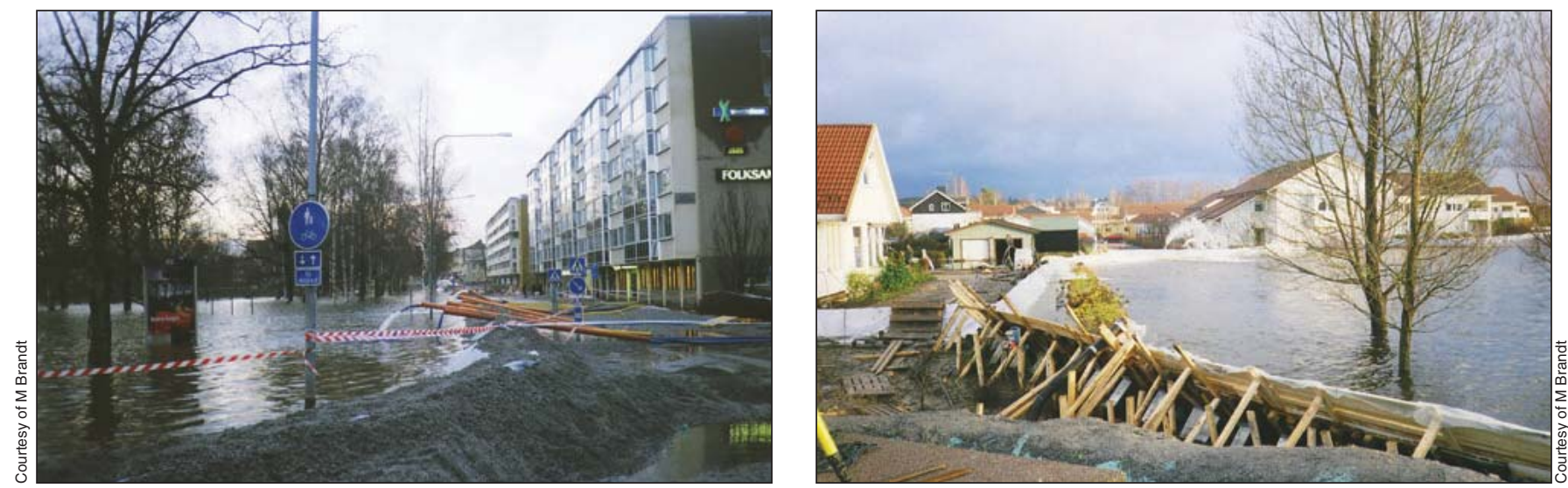

Figure 3. From November 2000 to January 2001, the town of Arvika and areas further downstream of the regulated Klar River valley in southern Sweden experienced a severe flood. The cost of repairing or compensating damage on buildings, infrastructure, agriculture, and fishing, and of the rescue work amounted to more than US\$60 million.

Asia, the Ganges, Hai He, Liao, and parts of the Huang He and Amur in Asia, and the Australian Murray-Darling. Interestingly, a few basins that are expected to gain water under future climates will still remain severely water stressed (eg the Colorado, the Hindus, Hai).

Areas of large river basins almost certain to require management intervention of some sort amount to approximately $700000 \mathrm{~km}^{2}$ for basins unimpacted by dams and 5 million $\mathrm{km}^{2}$ for dam-impacted basins (representing 1\% and $6.8 \%$ of the world's large river basin area, respectively), and come to represent $4.2 \%$ of the entire world's area when summed. Approximately 365 million people live in areas almost certain to require a concerted response (CIESIN and CIAT 2005). Basins in this category not impacted by dams include the Coppename in South America and large parts of the Lake Chad system in Africa. The strongest example of a dam-impacted basin in this category is the Nile in Africa, with additional examples including the Parnaiba in South America, the Indus, Cauvery, parts of the Ganges-Brahmaputra system in south Asia, parts of Syr-Darya in central Asia and the Tigris-Euphrates in the Middle East, parts of the Huang $\mathrm{He}$ in eastern Asia, and parts of the Colorado, Sacramento, and Columbia in western North America.

Increasing water demand related to economic and population growth may dominate the effects of climate change on overall available water for many rivers (Vörösmarty et al. 2000; Alcamo et al. 2007) and this will be exacerbated in dam-impacted basins (Figure 2). For example, even though the Ganges-Brahmaputra system should experience increases in combined surface runoff and groundwater recharge, withdrawals will greatly tax or even exceed this amount in many Ganges sub-basins and around the mouth of the system. In contrast, despite large decreases in available water in the Amazon, withdrawals will remain low enough to prevent water stress.

In addition to changes in annual discharge, an increase in extreme floods and droughts will impact river basins, particularly in northern Europe, northern China, western India, and Argentina under the scenarios and climate projections considered in this paper (Alcamo et al. 2007). The trends toward more intense hurricanes (Emanuel 2005; Webster et al. 2005) and rising sea levels (Meehl et al. 2005) may also continue, increasingly affecting river basins. In addition, increased frequency of low-flow conditions in southern Europe, Turkey, the Middle East, the middle-lower US, northern Latin America, and southern Australia may be extremely important (Milly et al. 2005).

\section{Expected consequences}

The changes in river discharge we have described will have far-reaching ecological and geomorphic effects, especially where natural flow regimes of water and sediment are already disrupted, such as in impounded rivers and even free-flowing rivers within developed catchments. In such situations, serious impacts, such as the alteration of material fluxes and/or connectivity, are anticipated under increased as well as decreased runoff. Overall, our analysis clearly suggests that, due to changes in discharge (Table 1; Figure 1) and water stress (Figure 2), the area of large river basins in need of reactive or proactive management interventions will be much higher for basins impacted by dams than for basins with free-flowing rivers.

In areas that gain water, rivers surrounded by intense development and river reaches above dams may experience more severe floods and increased erosion; in addition, aquatic organisms (including exotics) may be more easily dispersed and water quality reduced because of increased sediment, nutrient, and pollutant flux (Nelson et al. in review). Reservoir lifespan could decrease because of increased sediment storage, further amplifying flood risks and, if reservoirs are near capacity, the risk of breaches or dam failure will be great. While dams have saved the lives of many people by preventing floods, dams at risk of failure under future scenarios may pose the greatest threats to humans, infrastructure, crops, and livestock (Figure 3).

At the opposite end of the spectrum, impounded rivers that lose water may not be able to maintain their chan- 
Table 2. Management intervention actions recommended for major, dammed river systems, given expected changes in water availability

\begin{tabular}{|c|c|c|}
\hline \multirow[t]{2}{*}{ Type of management action } & \multicolumn{2}{|c|}{ Expected change in water availability in dammed basins } \\
\hline & Increase & Decrease \\
\hline $\begin{array}{l}\text { Stormwater and sediment } \\
\text { management (includes } \\
\text { wetland creation) }\end{array}$ & $\begin{array}{l}\text { New designs needed to reduce runoff and } \\
\text { sediment flux to rivers and reservoirs; use to } \\
\text { store flood water in uplands and wetlands }\end{array}$ & $\begin{array}{l}\text { Implement more to increase infiltration and } \\
\text { retain water in uplands and wetlands }\end{array}$ \\
\hline Channel reconfiguration & $\begin{array}{l}\text { Some configurations may help channel withstand } \\
\text { peak flow releases, especially important if risk } \\
\text { of dam failure is high }\end{array}$ & $\begin{array}{l}\text { Use to increase water retention and/or correct } \\
\text { past channelization }\end{array}$ \\
\hline Dam removal/retrofit & $\begin{array}{l}\text { Retrofit with temperature and water-quality } \\
\text { control devices; remove dams at high risk of failure }\end{array}$ & $\begin{array}{l}\text { Remove dams in areas with high evaporation; adjust } \\
\text { outlet height on dam to release high-quality water }\end{array}$ \\
\hline $\begin{array}{l}\text { Floodplain restoration } \\
\text { (including levee set-backs or } \\
\text { removal) }\end{array}$ & $\begin{array}{l}\text { Implement to allow overbank flows (may require land } \\
\text { acquisition or easements along river margins) }\end{array}$ & $\begin{array}{l}\text { Needed to enhance groundwater recharge and } \\
\text { remove barriers to dispersal }\end{array}$ \\
\hline Water-quality management & $\begin{array}{l}\text { Fortify dams to store excess sediment and pollutant } \\
\text { loads in reservoirs; modify dam outlets to release } \\
\text { high-quality water }\end{array}$ & $\begin{array}{l}\text { Modify dam outlets to release high-quality water; } \\
\text { limit extraction }\end{array}$ \\
\hline Land acquisition & $\begin{array}{l}\text { Restore floodplains and return land around reservoirs } \\
\text { to more vegetated state }\end{array}$ & $\begin{array}{l}\text { Limit floodplain encroachment and protect drying } \\
\text { catchments }\end{array}$ \\
\hline $\begin{array}{l}\text { Conjunctive groundwater/ } \\
\text { surface-water management }\end{array}$ & $\begin{array}{l}\text { Design structures for temporary storage of flood } \\
\text { waters before they reach reservoir }\end{array}$ & $\begin{array}{l}\text { Develop methods to divert surface water to ground- } \\
\text { water storage to provide water for later use (less } \\
\text { evaporative loss than in reservoirs) }\end{array}$ \\
\hline Fish passage & na & Retrofit existing but inadequate passages \\
\hline $\begin{array}{l}\text { Flow modification } \\
\text { (dam operations) }\end{array}$ & $\begin{array}{l}\text { Store and release water to/from reservoirs to avoid/ } \\
\text { abate floods and the risk of dam failure }\end{array}$ & $\begin{array}{l}\text { Implement strategic releases of water to provide } \\
\text { downstream flows during droughts }\end{array}$ \\
\hline Bank stabilization & Needed if banks erode due to higher peak flow releases & $\begin{array}{l}\text { Needed if banks dry and/or more variable flow releases } \\
\text { cause erosion }\end{array}$ \\
\hline Riparian management & $\begin{array}{l}\text { Revegetate damaged areas to slow runoff and temper } \\
\text { need for peak flow releases }\end{array}$ & $\begin{array}{l}\text { Remove drought-tolerant exotic species; plant natives } \\
\text { unable to disperse to river reaches that are now } \\
\text { isolated }\end{array}$ \\
\hline In-stream habitat improvements & Needed if increased peak flow releases simplify channel & As flow declines, add habitat to hold water \\
\hline
\end{tabular}

nels as they become less dynamic, resulting in degraded aquatic habitats. If water levels fall, land-water connectivity will be reduced and upland vegetation, probably with a large proportion of exotics, will likely encroach on the originally water-filled channels. Reservoirs may lose even more water due to evaporation, with concomitant increases in water temperature and declines in water quality. There is also a risk of increased rates of water extraction in response to water scarcity, implying that even more rivers might run dry. While increases in discharge may yield positive or negative effects for riverine biota, decreases from current levels of discharge will likely generate only adverse impacts, potentially leading to substantial declines in biodiversity (eg Xenopoulos et al. 2005).

Many of the potential changes will not only be harmful to ecosystems and human societies, but will also be costly to deal with, both socially and economically. For all types of river basins (dam-impacted; few/no dams and undeveloped; few/no dams and developed) and under both runoff changes (increase versus decrease), both proactive and reactive management strategies will be applicable (Table 2). Most of the management actions, particularly those related to flood mitigation, are well known to natural resource managers and thus could be implemented with sufficient funding and political will. It is easier to devise feasible strategies for floods than for droughts, even though the former actions could be more expensive. In the case of droughts, we may be left with far fewer technical solutions, especially as human pressures to extract water grow and supplies diminish.

\section{The need for action and the costs of inaction}

Our analysis suggests that many of the management actions that are needed arise directly from changes in the frequency and magnitude of extreme events, in addition to changes in average conditions. For example, in regions 

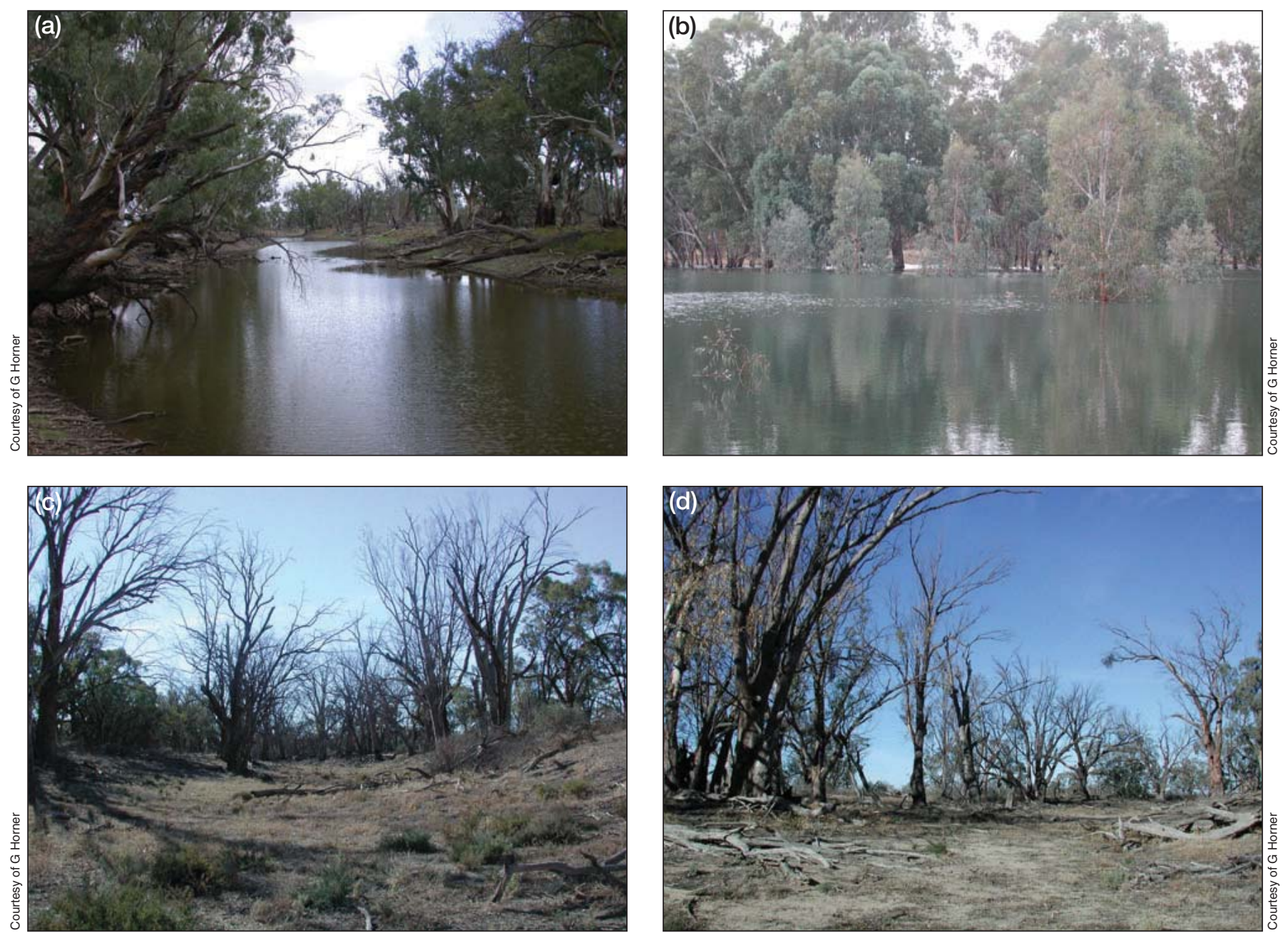

Figure 4. An example of proactive management, in which artificial floodplain inundation is maintaining river red gum (Eucalyptus camaldulensis) health on (a) Wallpolla and (b) Lindsay Islands on the Murray River floodplain in southeastern Australia. In neighboring areas of the Islands, ( $c$ and d) flow regulation and drought are causing widespread tree mortality. Reactive response will require widespread replanting and the forest will take decades to recover.

with increased discharge, projects involving additional stormwater control or modifications to dams or dam operation may be needed to protect ecosystems and people (Table 2). If these are not implemented proactively, rehabilitation projects to stabilize eroding riverbanks or reconfigure damaged river channels may be required and the costs may be high. In water-stressed areas, efforts involving wetland creation and floodplain reconnection may be needed to increase water retention and groundwater recharge (Figure 4). One could also imagine situations in which drier conditions lead to a need for stream banks to be stabilized or habitats improved (eg if the number of impoundments in the basin increased because of water shortages).

Free-flowing rivers in largely undeveloped watersheds are expected to be resilient in the face of climate change, while the need for restoration/rehabilitation and proactive management may be quite high in dammed and otherwise developed river systems. The high amounts of impervious coverage found in developed areas limit a basin's ability to store water and mitigate extremes in runoff, as well as its ability to reduce transport of contaminants from land to water. The dams and reservoirs themselves are of particular concern. Storage capacity of reservoirs may be limited, especially under increased runoff, because of larger sediment inputs, and dams may fail as a result of increased discharge. Under conditions of reduced runoff in warming regions, reservoirs will aggravate water deficits as a result of evaporation. In such cases, it may be worthwhile to store water elsewhere, in wetter areas with lower evaporation. For example, highevaporation, low-altitude dams may need to be decommissioned and their water stored in an alternate location. Such efforts will be extremely expensive and will require support from a variety of sectors, but their objectives are too important to be ignored or postponed.

The number of dams in the world is steadily increasing, probably for reasons that are only rarely connected with global climate change. A recent report (WWF 2004) identifies 21 river basins at severe risk of ecological degradation, as they have six or more dams over $60 \mathrm{~m}$ in existence, planned, or under construction. Each of these 
dams will interact in different ways with projected water stress (Figure 2), suggesting that plans should be put under review. For example, three clusters of new dams will be located in areas likely to experience either reduced water stress (lower central South America; Rio de la Plata), increased stress (the Middle East; Tigris-Euphrates), or relatively unchanged conditions (central China; Yangtze River).

Evaluating the economic costs of taking management or restoration action versus the costs incurred if nothing is done is difficult because so many factors could potentially be considered. In some cases, taking action may be cheaper than repairing damage at a later time. For example, we considered the economic costs of river flooding versus the costs of restoring floodplains and managing flows to mitigate floods. While, in the US, no single agency is responsible for collecting and evaluating detailed loss information from river floods, the National Oceanic and Atmospheric Administration's National Weather Service, through its numerous field offices, provides annual loss estimates for major flood events. These estimates have increased from a value of $\$ 3.97$ billion in 1903 to a value of $\$ 13.97$ billion in 2004 (inflation adjusted to the year 2004; National Weather Service 2006). Yet in the US, total annual estimated expenditures on river restoration are only $\sim \$ 1$ billion (2004 dollars), and only a small fraction of that money goes toward restoration or rehabilitation efforts that would reduce flooding (eg levee removal to restore floodplains, flow management; Bernhardt et al. 2005). If we consider that proactive strategies may prevent flooding and the damage it causes for many years, the cumulative savings could be enormous. While this one example suggests that taking action may be economically beneficial, some actions are likely to be extremely expensive, including dam removal or engineering the storage of water.

\section{Conclusions}

Our analysis suggests that, within 50 years, river basins that are impacted by dams or by extensive development will experience greater changes in discharge and water stress than unimpacted, free-flowing rivers. Since ecological and societal costs may be substantial, strategies for coping with expected problems are worth pursuing and we offer a number of examples of such strategies that many natural resource managers are already using. Higher resolution climate-change forecasts for specific basins or sub-basins and strategies developed within the context of local economies and societal needs are vital in order to fully develop and implement site-specific action plans. Proactive measures that restore the natural capacity of rivers to buffer climatechange impacts are obviously the most desirable actions, since they may also lead to environmental benefits, such as higher water quality and restored fish populations. Examples of such measures might include stormwater management in developed basins or, even better, land acquisition around the river to free the floodplain of infrastructure and allow regrowth of riparian vegetation. In contrast to many short-term reactive measures, these proactive measures will need to be undertaken at large spatial scales to work effectively. Thus, if we are to successfully implement proactive strategies, the time to start is now. Delays in the implementation of proactive forms of restoration, rehabilitation, and river management will inevitably exacerbate the effects of global climate change on efforts to balance the needs of humans and rivers.

\section{Acknowledgements}

This work was supported by the US Environmental Protection Agency Global Climate Change Program 1W0594NAEX and R83038701, the Swedish Research Council and the Swedish Research Council Formas, Land and Water Australia, Water CRC Australia, the DFG-German Research Foundation and the International Water and Climate Dialogue. Contribution Number 4094 of the University of Maryland Center for Environmental Science, Chesapeake Biological Laboratory.

\section{References}

Alcamo J, Döll P, Henrichs T, et al. 2003a. Development and testing of the WaterGAP 2 global model of water use and availability. Hydrol Sci J 48: 317-37.

Alcamo J, Döll P, Henrichs T, et al. 2003b. Global estimates of water withdrawals and availability under current and future "business-as-usual" conditions. Hydrol Sci J 48: 339-48.

Alcamo J, van Vuuren D, Ringler C, et al. 2005. Changes in nature's balance sheet: model-based estimates of future worldwide ecosystem services. Ecol Soc 10: 19.

Alcamo J, Flörke M, and Maerker M. 2007. Future long-term changes in global water resources driven by socio-economic and climatic changes. Hydrol Sci 52: 247-75.

Allan JD, Palmer MA, and Poff NL. 2005. Freshwater ecology. In: Lovejoy TE and Hannah L (Eds). Climate change and biodiversity. New Haven, CT: Yale University Press.

Bernhardt ES, Palmer MA, Allan JD, et al. 2005. Synthesizing US river restoration efforts. Science 308: 636-37.

Bunn SE and Arthington AH. 2002. Basic principles and ecological consequences of altered flow regimes for aquatic biodiversity. Environ Manage 30: 563-07.

CIESIN (Center for International Earth Science Information Network) and CIAT (Centro Internacional de Agricultura Tropical). 2005. Gridded population of the world version 3 (GPWv3): population grids. Palisades, NY: Socioeconomic Data and Applications Center (SEDAC), Columbia University. http://sedac.ciesin.columbia.edu/gpw. Viewed 12 Jun 2007.

Cosgrove W and Rijsberman F. 2002. World water vision: the report of the World Water Commission. London, UK: Earthscan.

Döll P, Kaspar F, and Lehner B. 2003. A global hydrological model for deriving water availability indicators: model tuning and validation. J Hydrol 270: 105-34.

Emanuel K. 2005. Increasing destructiveness of tropical cyclones over the past 30 years. Nature 436: 686-88.

Global Land Cover 2000 Database. 2003. European Commission, Joint Research Centre. http://www-gvm.jrc.it/glc2000/. Viewed 18 Sep 2007.

Hulme PE. 2005. Adapting to climate change: is there scope for ecological management in the face of a global threat? J Appl Ecol 43: 617-27.

IPCC (Intergovernmental Panel on Climate Change). 2000. 
Special report on emission scenarios. Cambridge, UK: Cambridge University Press.

Kaspar F. 2004. Development and uncertainty analysis of a global hydrologic model (PhD dissertation). Kassel, Germany: University of Kassel.

Lettenmaier DP, Wood AW, Palmer RN, et al. 1999. Water resources implications of global warming: a US regional perspective. Climate Change 43: 537-79.

Meehl GA, Washington M, Collins WD, et al. 2005. How much more global warming and sea level rise? Science 307: 1769-72.

Milly PCD, Dunne KA, and Vecchia AV. 2005. Global pattern of trends in streamflow and water availability in a changing climate. Nature 438: 347-50.

Naiman RJ, Décamps H, and McClain ME. 2005. Riparia: ecology, conservation, and management of streamside communities. Amsterdam, Netherlands: Elsevier.

National Weather Service. 2006. Hydrologic Information Center. Flood loss: compilation of flood loss statistics. www.weather. gov/oh/hic/flood_stats/Flood_loss_time_series.shtml. Viewed 12 Jun 2007.

Nelson K, Palmer MA, Pizzuto J, et al. Ecological forecasting in a complex world: urbanization, climate change, and headwater streams. J Appl Ecol. In review.

Nilsson C, Reidy CA, Dynesius M, and Revenga C. 2005. Fragmentation and flow regulation of the world's large river systems. Science 308: 405-08.

Palmer MA, Lettenmeier D, Postel S, et al. 2007. Adaptation options for climate-sensitive ecosystems and resources: wild and scenic rivers. Washington, DC: US Climate Change Science Program. Synthesis and assessment product 4.4.

Payne JT, Wood AW, Hamlet AF, et al. 2004. Mitigating the effects of climate change on the water resources of the Columbia River Basin. Climate Change 62: 233-56.

Pinter N. 2005. One step forward, two steps back on US floodplains. Science 308: 207-08.

Poff NL, Allan JD, Bain MB, et al. 1997. The natural flow regime: a new paradigm for riverine conservation and restoration BioScience 47: 769-84.

Poff NL, Brinson MM, and Day JW. 2002. Aquatic ecosystems and global climate change: potential impacts on inland freshwater and coastal wetland ecosystems. Arlington, VA: US Pew Center for Global Change.

Poff NL, Olden JD, Merritt DM, and Pepin DM. 2007. Homogenization of regional river dynamics by dams and global biodiversity implications. Proc Natl Acad Sci USA 104: 5732-37.

Postel S and Richter B. 2003. Rivers for life: managing water for people and nature. Washington, DC: Island Press.

Schröter D, Cramer W, Leemans W, et al. 2005. Ecosystem service supply and vulnerability to global change in Europe. Science 310: $1333-37$.

Surian N and Rinaldi M. 2003. Morphological response to river engineering and management in alluvial channels in Italy. Geomorphology 50: 307-26.

Tennant DL. 1976. Instream flow regimens for fish, wildlife, recreation, and related environmental resources. Fisheries 4: 6-10.

Tharme RE. 2003. A global perspective on environmental flow assessment: emerging trends in the development and application of environmental flow methodologies for rivers. River Res Appl 19: 397-442.

Vörösmarty CJ, Green P, Salisbury J, and Lammers RB. 2000. Global water resources: vulnerability from climate change and population growth. Science 289: 284-88.

Webster PJ, Holland GJ, Curry JA, and Chang H-R. 2005. Changes in tropical cyclone number, duration, and intensity in a warming environment. Science 309: 1844-46.

WWF (World Wildlife Fund). 2004. Rivers at risk: dams and the future of freshwater ecosystems. www.panda.org/downloads/ freshwater/riversatriskfullreport.pdf. Viewed 12 Jun 2007.

Xenopoulos MA, Lodge DM, Alcamo J, et al. 2005. Scenarios of freshwater fish extinctions from climate change and water withdrawal. Global Change Biol 11: 1557-64. 